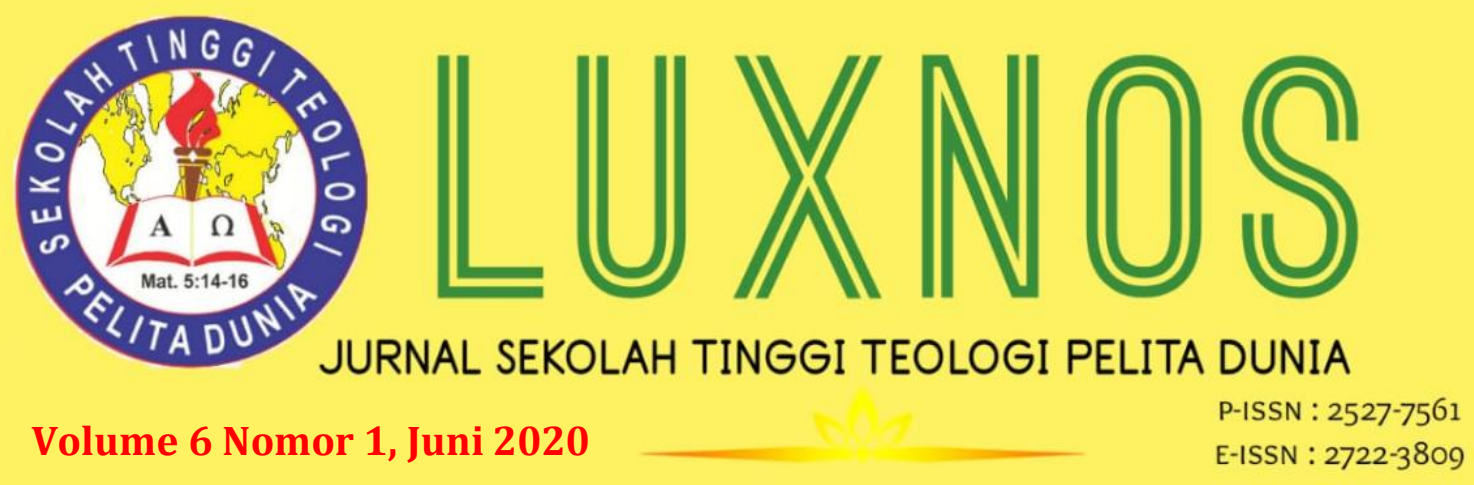

\title{
Problematika Tentang Boleh Tidaknya Hamba Tuhan Merokok
}

\author{
Sri Dwi Harti, Sekolah Tinggi Teologi Pelita Dunia Tangerang, \\ dwiharti@hotmail.com
}

\begin{abstract}
This research is about literature study on whether or not a servant of God smokes. This research was carried out based on the observation of researchers that there are still many servants of God who smoke, both openly and quietly. By using a qualitative approach and focusing on data or information from the literature, the results are obtained that should servants of God should not smoke. This result is also based on several perspectives such as: medical, ethical, legal and especially on the Bible.
\end{abstract}

Keywords: God's Servant, Smoking, Problematics

\begin{abstract}
Abstraksi: Penelitian ini tentang kajian pustaka terhadap boleh tidaknya seorang hamba Tuhan merokok. Penelitian ini dilakukan berdasarkan pengamatan peneliti bahwa masih banyak hamba Tuhan yang merokok, baik yang terang-terangan maupun yang sembunyi-bunyi. Dengan menggunakan pendekatan kualitatif dan menitikberatkan pada data atau informasi dari literatur maka diperoleh hasil bahwa seharusnya hamba Tuhan tidak boleh merokok. Hasil ini juga didasarkan pada beberapa perspektif seperti: medis, etis, hukum dan terutama pada Alkitab.

Kata Kunci: Hamba Tuhan, Merokok, Problematika
\end{abstract}

\section{Pendahuluan}

Hamba Tuhan yang dimaksud dalam tulisan dan penelitian ini adalah mereka yang bekerja dan berkomitmen mengerjakan setiap pelayanan dan pekerjaan Tuhan. Baik dalam konteks penatalayanan di gereja, maupun pemberitaan Injil (misionaris), bahkan setiap dosen-dosen teologi yang memang telah mengikuti studi Alkitab dan teologi di seminari-seminari teologi.

Sebagai hamba Tuhan, tentunya mereka hidup dan menghidupi keluarganya dari pelayanan yang dilakukan. Itulah sebabnya, dalam kitab Maleakhi Tuhan menjadi marah karena orang Israel tidak lagi memberikan persembahan persepuluhan, sehingga berdampak kepada kehidupan para imam (orang Lewi) menjadi kekurangan. Padahal mereka hanya hidup dari pelayanan mereka. Seperti yang dikemukakan oleh Afgrita 
Fendy Christiawan, "Mereka juga sudah lama tidak menjalankan persembahan persepuluhan sehingga tempat perbendaharaan tidak terisi dan tidak ada makanan bagi orang Lewi".1

Artinya, setiap hamba Tuhan sama halnya orang Lewi yang hanya hidup dari pelayanan yang dikerjakan. Jadi penghasilan mereka hanya diperoleh dari setiap persembahan jemaat. Lalu, apakah pantas setiap penghasilan yang diperoleh dari pelayan dapat dihambur-hamburkan untuk membeli sesuatu yang tidak bermanfaat bahkan dapat merusak kesehatan, seperti rokok, dll. Hal inilah yang akan diuraikan dalam penelitian ini untuk mencari tahu, apakah boleh seorang hamba Tuhan merokok, mengingat bahwa mereka adalah orang-orang yang dikhususkan Allah untuk melakukan pelayanan-pelayanan untuk Tuhan serta mengingat bahwa sumber utama keuangan seorang hamba Tuhan dalam memenuhi kebutuhan kehidupan mereka hanyalah dari pelayanan tersebut?

Yakub Tri Handoko memberikan komentar tentang rokok yang sama sekali tidak ada manfaatnya. Hal itu dikemukakan sebagai berikut:

Pertama, merokok tidak membawa keuntungan apapun, baik bagi diri sendiri maupun orang lain. Paulus mengajarkan bahwa kebebasan di dalam Kristus tidak berarti kebebasan yang liar. Ada banyak aspek yang tetap perlu untuk dipertimbangkan. Salah satunya adalah aspek manfaat. Paulus berkata: "Segala sesuatu halal bagiku, tetapi tidak semua berguna" (1Kor. 6:12). Berguna di sini selanjutnya dipahami dalam konteks "membangun" (1Kor. 10:23). Sampai sekarang belum ada studi yang mengungkapkan manfaat merokok bagi kesehatan. Sebaliknya, banyak riset menunjukkan sebaliknya. Merokok sangat berbahaya, baik bagi perokok sendiri atau orang lain di sekitarnya. Kedua, merokok bersifat adiktif. Aspek lain dalam etika Kristiani adalah ketergantungan atau kecanduan. 1 Korintus 6:12 juga mengajarkan hal ini: "Segala sesuatu halal bagiku, tetapi aku tidak membiarkan diriku diperhamba oleh suatu apapun". Kecanduan juga merupakan tanda ketidakadaan pengendalian diri, padahal tanda ini seharusnya nampak pada mereka yang dipenuhi oleh Roh Kudus (Gal. 5:22-23). Ketiga, merokok tidak memuliakan Tuhan. Setiap orang Kristen seyogyanya melakukan segala sesuatu untuk kemuliaan Tuhan, bahkan untuk hal-hal yang sepele dan rutin sekalipun. Paulus mengajarkan: "Jika engkau makan atau jika engkau minum, atau jika engkau melakukan sesuatu yang lain, lakukanlah semuanya itu untuk kemuliaan Allah" (1Kor. 10:31). Saya tidak bisa melihat bagaimana merokok dapat memuliakan Tuhan. Sebaliknya, tindakan yang bisa merusak kesehatan ini justru terlihat bertabrakan dengan penebusan Kristus atas tubuh kita (1Kor. 6:19-20). Tubuh yang sudah ditebus dengan mahal seharusnya dipelihara dengan baik.2

Berdasarkan apa yang dikemuka oleh oleh Yakub Tri Handoko di atas, maka dapat dikatakan bahwa merokok atau rokok sama sekali tidak memberikan manfaat kepada setiap perokok. Justru hanya akan menimbulkan kerugian dan penyakit. lalu, dapatkah dibenarkan seorang hamba Tuhan merokok, padahal sudah jelas bahwa itu sama sekali merugikan.

${ }^{1}$ https://jurnal.i3batu.ac.id/index.php/me/article/view/81

${ }^{2}$ http://rec.or.id/article_943_Apakah-Orang-Kristen-Boleh-Merokok?/21/04/2020//. 


\section{Metode Penelitian}

Pada penelitian ini menggunakan metode kualitatif, khususnya pendekatan pustaka untuk memperoleh sebuah konsep dan pemahaman yang benar dan kualitatif perihal boleh tidaknya seorang hamba Tuhan merokok.

\section{Hasil dan Pembahasan}

Berikut ini dikemukakan ulasan rokok atau merokok dari beberapa perspektif. Ini dikemukakan bertujuan untuk membentuk konsep dan pemahaman kita tentang untung atau ruginya merokok. Sehingga berangkat dari situ, kita dapat menyimpulkan apakah seorang hamba Tuhan boleh atau tidak boleh merokok.

Dari perspektif Kesehatan. Lula Nadia mengatakan, "Telah banyak penelitian yang dilakukan oleh para peneliti terhadap kejelekan akibat merokok terhadap kesehatan manusia. Terutama di negara-negara Barat, pengetahuan tentang kejelekan merokok demikian berkembang dan meluas..".3 bahkan ditambahkan oleh Nadia,

Tembakau berada pada peringkat utama penyebab kematian yang dapat dicegah di dunia. Merokok juga merupakan penyebab kematian satu dari 10 kematian orang dewasa di seluruh dunia, serta mengakibatkan 5,4 juta kematian pada tahun 2006, ini berarti rata-rata satu kematian setiap 6,5 detik (Jia-Xiang, 2014). Lebih lanjut Dr. Agus mengungkapkan bahwa pasien penderita kanker paru, penyakit paru obstruktif kronis (PPOK), stroke, dan jantung koroner, kebanyakan adalah perokok (Kompas, 25 Mei 2016). Menurut keadaan terkini, hampir 70\% perokok di Indonesia memulai merokok sebelum umur 19 tahun, bahkan data Susenas (Survei Sosial Ekonomi Nasional) 2003 meyebutkan usia 8 tahun sudah mulai merokok.4

Sedangkan menurut Tjandra Yoga Aditama, "Hasil penelitian di Inggris menunjukkan bahwa kurang lebih 50\% para perokok yang merokok sejak remaja akan meningggal akibat penyakit-penyakit yang berhubungan dengan kebiasaan merokok. Kebiasaan merokok telah terbukti berhubungan dengan kurang lebih 25 jenis penyakit dari berbagai organ tubuh manusia. Penyakit tersebut, antara lain: kanker mulut, esophagus, faring, laring, paru, pancreas, kandung kemih, dan penyakit pembuluh darah. Hal itu dipengaruhi pula oleh kebiasaan meminum alkohol serta factor lain".5

Berdasarkan informasi di atas, memang sama sekali tidak ada manfaat dari rokok atau merokok. Oleh karena yang ditimbulkan hanyalah penyakit bahkan bisa berujung kepada kematian. Lalu, untuk apa seorang hamba Tuhan merokok? Untuk merusak kesehatannya? Padahal Tuhan sudah memberikan tubuh yang sehat untuk digunakan melayani Tuhan, namun justru dirusak oleh rokok. Dengan demikian, dapat dilihat dari perspektif kesehatan, rokok sama sekali tidak memiliki faedah bagi kesehatan.

${ }^{3}$ http://repository.ut.ac.id/7088/1/UTFMIPA2016-04-lula.pdf, hlm. 78.

${ }^{4}$ http://repository.ut.ac.id/7088/1/UTFMIPA2016-04-lula.pdf, hlm. 81

${ }^{5}$ Tjandra Yoga Aditama, Rokok Masalah Dunia, Jurnal Kedokteran dan Farmasi, No.9 Tahun XXI, (Jakarta: PT. Grafiti Medika Pers, 1995). 
Dari perspektif Etis. Secara etis, seorang hamba Tuhan adalah pemberita kabar baik, pemberita Injil, dan selalu menjadi contoh maupun teladan dalam kehidupan sosial masyarakat. Oleh karena itu wajib hukumnya untuk mereka selalu memperlihatkan sikap dan tindakan yang baik dan dapat diteladani oleh jemaat. Bahkan mereka juga harus menggunakan setiap penghasilan dari pelayanan untuk hal-hal yang positif dan bermanfaat.

Bayangkan saja apabila ada seorang hamba Tuhan atau pendeta merokok di depan jemaat, padahal setiap minggu jemaat memberikan persembahan kepada Tuhan di gereja; dan jemaat juga tahu bahwa penghasilan hamba Tuhan itu hanya dari pelayanan. Namun ternyata hamba Tuhan itu justru menggunakan sebagian berkat dari Tuhan untuk membeli rokok yang sama sekali tidak ada manfaatnya bagi kesehatan tubuhnya. Sebaliknya, akan merusaknya dan memberikan penyakit bahkan sangat besar kemungkinan justru membawanya pada kematian.

Dari perspektif Hukum.Dari perspektif hukum, pemerintah juga membatasi dan mengatur setiap tindakan atau kebiasaan merokok masyarakat. Misalnya: Peraturan Pemerintah Republik Indonesia Nomor 109 Tahun 2012 tentang Pengamanan Bahan yang Mengandung Zat Adiktif Berupa Produk Tembakau bagi Kesehatan. Peraturan Menteri Perhubungan RI Nomor PM. 12 Tahun 2019 Pasal 6 yang berbunyi, "pengemudi dilarang merokok dan melakukan aktivitas yang lain yang mengganggu konsentrasi ketika sedang mengendarai sepeda motor".6

Berdasarkan analisis terhadap isi setiap peraturan dan perundang-undangan di atas, dapat diasumsikan bahwa terbitnya undang-undang itu tidak terlepas dari kesadaran pemerintah betapa bahayanya merokok. Oleh karena merokok tidak hanya merusak kesehatan, tetapi juga dapat mengganggu setiap aktivitas yang dilakukan di tempat-tempat umum. Itulah sebabnya, pemerintah mengaturnya dalam undangundang.

Sekali lagi, hal inipun menunjukkan bahwa sungguh rokok dan merokok itu tidak ada manfaatnya. Justru sebaliknya hanya akan merugikan. Seorang hamba Tuhan yang merokok bukannya menyebarkan kebaikan dan kehidupan, tetapi justru sebaliknya hanyalah menyebarkan keburukan baik bagi dirinya sendiri maupun bagi orang-orang disekitarnya karena telah menyebarkan racun asap rokoknya.

Dari Perspektif Alkitab.Apakah Alkitab juga berbicara larangan merokok? Memang secara tersurat Alkitab tidak ada menyatakan boleh atau tidak seseorang merokok. Akan tetapi ada beberapa ayat Alkitab yang dapat digunakan untuk menjadi acuan, bahwa betapa rokok dan merokok seharusnya tidak dilakukan oleh seorang hamba Tuhan.

Dalam 1 Korintus 6:19 berbunyi demikian; "Atau tidak tahukah kamu, bahwa tubuhmu adalah bait Roh Kudus yang diam didalam kamu, Roh Kudus yang kamu peroleh dari Allah,--dan bahwa kamu bukan milik kamu sendiri?”. Menurut V. C. Pfitzner, pada bagian ini Paulus berbicara tentang, "Gereja sebagai tubuh Kristus adalah bait Roh Kudus (3:16), tetapi masing-masing tubuh adalah bait Roh Kudus pula. Yesus pernah berbicara tentang bait suci yang baru dari tubuh-Nya sendiri (Yoh. 2:21). Roh-Nya kini

${ }^{6}$ https://otomotif.kompas.com/read/2019/04/06/161714715/larangan-merokok-sambil-berkendarasesuai-dengan-uu-no-22-tahun-2009//20/05/2020//. 
tinggal di dalam masing-masing orang percaya (Rm. 8:9)".7 R. Dean Anderson memberikan penjelasan yang kurang lebih sama dengan Pfitzner namun jauh lebih tegas menegaskan tentang tubuh orang Kristen sebagai bait Roh Kudus. Hal itu tampak dengan jelas dalam penjelasan Anderson yang mengatakan bahwa, "Roh sebagai Pribadi Allah sendiri membuat tubuh manusia menjadi istana-Nya yang kudus... Allah melalui Roh-Nya diam di dalam kita, dan sebab itu ikut dengan kita ke mana saja. Allah telah membeli kita dan membayar harganya dengan lunas. Sebab itu kita wajib memuliakan Dia”.8 Gordon Fee menambahkan,

Through the phenomenon of the indwelling Spirit, Paul now images the body as the Spirit's temple, emphasizing that it is the "place" of the Spirit's dwelling in the individual believers' lives. In the same way that the temple in Jerusalem "housed" the presence of the living God, so the Spirit of God is "housed" in the believer's body. This is imagery pure and simple, in which the significance of the body for the present is being affirmed; it is not intended to be a statement of Christian anthropology, as though the body were the mere external casing of the spirit or Spirit.9

Sebagai orang Kristen, tubuh adalah tempat tinggal pribadi Roh Kudus (juga lih. Rom 8:11 di mana Roh itu merupakan tanda dari Allah yang menyatakan bahwa kamu menjadi milik-Nya). Karena Roh itu tinggal di dalam diri setiap orang percaya maka dengan demikian mereka telah menjadi milik Allah. Oleh karena itu, tubuh orang percaya adalah bait Roh Kudus sama sekali tidak boleh dicemarkan oleh kenajisan atau kejahatan apa pun, baik oleh pikiran yang jahat, keinginan yang bertentangan dengan kehendak Allah, tindakan-tindakan kejahatan, film-film yang tidak membangun iman, buku-buku maupun majalah cabul dan termasuk merokok. Sebagai seorang hamba Tuhan harus hidup sedemikian rupa sehingga menghormati dan memuliakan Allah dengan tubuhnya (ay. 1Kor 6:20).10

Berdasarkan penjelasan-penjelasan di atas, maka dapat disimpulkan bahwa tubuh atau kehidupan hamba Tuhan telah dibeli dengan darah Kristus, di mana dalam konteks ini disebut sebagai Bait Allah. Sehingga tubuh dan kehidupan hamba Tuhan sepenuhnya adalah milik Kristus. Sehingga akan sangat tidak mungkin untuk seorang hamba Tuhan merokok. Mengapa? Karena seperti penjelasan di atas, bahwa rokok dan merokok dapat membuat tubuh seseorang menjadi rusak dan sakit bahkan mati.

Roma 12:1. Menurut Th. van den End,"Maka inilah yang hendak Paulus katakan di sini. Seluruh pikiran, perkataan, dan perbuatan, pokoknya seluruh kemampuan dan kegiatan kita, harus dipersembahkan kepada Tuhan".11Orang percaya seharusnya mempunyai keinginan tulus-ikhlas untuk menyenangkan hati Allah dalam kasih, pengabdian, pujian dan kekudusan, serta mempersembahkan tubuh untuk pelayanan. Keinginan terbesar kita seharusnya hidup kudus dan berkenan kepada Allah. Ini

7 V.C. Pfitzner, Ulasan Atas 1 Korintus: Kesatuan dalam Kepelbagaian, (Jakarta: BPK Gunung Mulia,2011), hlm. 103.

${ }^{8}$ R. Dean Anderson, Surat 1 Korintus: Membereskan Jemaat Urban yang Muda, (Surabaya: Momentum, 2018), hlm. 134.

${ }^{9}$ Gordon D. Fee, The International Commentary on the New Testament: The First Epistle to the Corinthians, (GrandRapids, Michigan: William B. Eerdmans Publishing, 1988), 264

${ }^{10} \mathrm{https}$ ://alkitab.sabda.org/commentary.php?book=46\&chapter=6\&verse=19//20/02/2020//.

11 Th. van den End, Tafsiran Alkitab: Surat Roma, (Jakarta: BPK Gunung Mulia,2006), hlm. 653. 
menuntut setiap hamba Tuhan harus memisahkan diri dari dunia dalam berpikir mapun bertindak dan makin mendekati pada kehendak Allah (ayat Rom 12:2). (1) Kita harus hidup bagi Allah, menyembah Dia, mentaati Dia, bersama dengan Dia menentang dosa dan membela kebenaran, menolak dan membenci kejahatan, melakukan pekerjaan baik untuk orang lain, meniru Kristus, mengikut Dia, melayani Dia, hidup sesuai dengan pimpinan Roh. (2)Kita harus mempersembahkan tubuh kita kepada Allah sebagai rumah Roh Kudus (Rom 12:2, bdk. 1Kor 6:15,19).12 Douglas Moo menambahkan,

Thus the Christian is called to a worship that is not confined to one place or to one time, but which involves all places and all times: "Christian worship does not consist of what is practiced at sacred sites, at sacred times, and with sacred acts. $\ldots$ It is the offering of bodily existence in the otherwise profanesphere."Chrysostom comments: "And how is the body, it may be said, to become a sacrifice? Let the eye look on no evil thing, and it hath become a sacrifice; let thy tongue speak nothing filthy, and it hath become an offering; let thine hand do no lawless deed, and it hath become a whole burnt offering." Regular meetings together of Christians for praise and mutual edification are appropriate and, indeed, commanded in Scripture. And what happens at these meetings is certainly "worship." But such special times of corporate worship are only one aspect of the continual worship that each of us is to offer the Lord in the sacrifice of our bodies day by day.13

Pada intinya Moo menegaskan bahwa setiap orang Kristen dipanggil untuk beribadah yang tidak terbatas pada satu tempat atau satu waktu, tetapi yang melibatkan semua tempat dan sepanjang waktu: "Ibadah Kristen tidak terdiri dari apa yang dipraktikkan di situs suci, pada waktu sakral, dan dengan sakral tindakan. Itu adalah persembahan keberadaan jasmani di tempat lain yang profan. Moo juga mengutip pendapat Chrysostom yang berkomentar: "Dan bagaimana tubuh, dapat dikatakan, untuk menjadi korban? Biarkan mata melihat pada tidak ada hal yang jahat, dan itu telah menjadi korban; biarlah lidahmu tidak berbicara apa-apa yang kotor, dan itu telah menjadi persembahan; biarlah tanganmu tidak melakukan pelanggaran hukum, dan itu telah menjadi korban bakaran yang utuh". Dengan demikian bagi Moo, pertemuan rutin bersama orang Kristen untuk pujian dan saling membangun adalah pantas dan, memang, diperintahkan dalam Alkitab. Dan apa yang terjadi pada pertemuan-pertemuan ini tentu saja "ibadah." Tetapi saat-saat istimewa ibadat bersama seperti itu hanyalah satu aspek dari ibadat yang berkelanjutan yang masing-masing dari kita harus mempersembahkan kepada Tuhan dalam pengorbanan tubuh kita hari demi hari.

Dengan demikian, prinsip untuk mempersembahkan totalitas hidup atau tubuh kepada Kristus sama sekali menegasi (meniadakan) tindakan merusak tubuh melalui rokok atau merokok. Memang secara tersurat ayat ini tidak menyinggung tentang rokok namun penegasan bahwa kita harus memiliki tubuh yang kudus dan total harus dipersembahkan kepada Kristus, maka hal itupun telah menggugurkan dan menolak tindakan merokok yang dilakukan oleh hamba-hamba Tuhan.

${ }^{12}$ https://alkitab.sabda.org/commentary.php?book=rom \&chapter=12\&verse=1/20/02/2020//.

13 Douglas Moo, The International Commentary on the New Testament: The Epistle to the Romans, (GrandRapids, Michigan: William B. Eerdmans Publishing, 1996), hlm. 754. 


\section{JURNAL LUXNOS \\ Volume 6 Nomor 1, Juni 2020}

Dalam 1 Petrus 1:18-19 berbunyi demikian; "Sebab kamu tahu, bahwa kamu telah ditebus dari cara hidupmu yang sia-sia yang kamu warisi dari nenek moyangmu itu bukan dengan barang yang fana, bukan pula dengan perak atau emas, melainkan dengan darah yang mahal, yaitu darah Kristus yang sama seperti darah anak domba yang tak bernoda dan tak bercacat".. Menurut P.H.R. van Houwelingen, "Petrus mungkin menyinggung perbuatan sia-sia berupa berbagai kegiatan keagamaan bangsa, seperti yang misalnya dapat ditemukan di Listra (Kis. 14:15). Tradisi-tradisi yang sudah sangat kuno menjadi bentuk-bentuk yang tiada arti. Betapa kosong dan sia-sianya adat istiadat dan kebiasaan tradisional yang diteruskan dari ayah kepada anaknya, dibandingkan dengan apa yang diteruskan dari sang Bapa kepada anak-anak-Nya".14

Berdasarkan apa yang dikemukakan oleh Houwelingen di atas, maka dapat dilihat dengan jelas sebuah prinsip hidup sebagai orang Kristen atau hamba Tuhan secara khusus. Menurutnya, hidup hamba Tuhan harus fokus pada pelayanan pemberitaan Injil Kristus. Sehingga hamba Tuhan tidak boleh lagi mengisi hidupnya dengan hal-hal yang sia-sia. Dalam hal ini, termasuk merokok atau rokok adalah hal yang sia-sia dan tidak berguna sehingga diharamkan untuk dilakukan. Karena rokok dapat membuat tubuh kita sakit dan akhirnya dapat menghalangi kita dalam melayani Kristus. Tubuh hamba Tuhan adalah Bait Allah atau Bait Roh Kudus yang harus dipergunakan seutuhnya untuk melayani-Nya.

Berdasarkan penjabaran dan penjelasan di atas, setelah memperhatikan dan menganalisis beberapa perspektif (medis, hukum, etis hingga Alkitab), maka berikut ini akan diuraikan beberapa hasil penelitian ini:

1. Rokok dan merokok merupakan hal yang tidak diperlukan oleh tubuh manusia. Apabila tetap digunakan maka akan merusak dan berdampak negatif terhadap tubuh manusia. Karena rokok banyak mengandung zat kimia berbahaya.

2. Berdasarkan perspektif medis, etis, hukum, hingga Alkitab, maka ditemukan tidak ada yang positif atau bermanfaat dari rokok atau merokok.

3. Apakah hamba Tuhan boleh merokok? Secara prinsip Alkitab tentu tidak boleh. Dan berdasarkan pertimbangan yang lain, maka rokok sama sekali tidak bermanfaat. Sehingga dengan demikian tidak ada satu alasan pun yang bersifat positif dapat menjadi satu dasar yang kuta bagi seorang hamba Tuhan untuk boleh merokok. Dengan merokok, maka hamba Tuhan telah menempatkan dirinya pada posisi yang sama dengan dunia.

\section{Kesimpulan}

Setelah melalui proses penelitian, dan berdasarkan penjelasan dan hasil penelitian di atas, maka dapat disimpulkan bahwa hamba Tuhan tidak boleh merokok. Oleh karena merokok atau rokok dapat merusak tubuh seseorang. Dan apabila dilakukan, maka sama halnya hamba Tuhan sedang merusak tubuhnya yang telah ditebus oleh Kristus dan sekarang telah menjadi Bait Roh Kudus.

\section{Referensi}

https://jurnal.i3batu.ac.id/index.php/me/article/view/81

14 P.H. R. van Houwelingen, Tafsiran Perjanjian Baru: Surat 1 Petrus, (Surabaya: Momentum, 2018), hlm.100-101. 
http://rec.or.id/article_943_Apakah-Orang-Kristen-Boleh-Merokok?/21/04/2020//. http://repository.ut.ac.id/7088/1/UTFMIPA2016-04-lula.pdf, hlm. 78. http://repository.ut.ac.id/7088/1/UTFMIPA2016-04-lula.pdf, hlm. 81 Aditama, Tjandra Yoga, Rokok Masalah Dunia, Jurnal Kedokteran dan Farmasi, No.9 Tahun XXI, Jakarta: PT. Grafiti Medika Pers, 1995.

https://otomotif.kompas.com/read/2019/04/06/161714715/larangan-merokoksambil-berkendara-sesuai-dengan-uu-no-22-tahun-2009//20/05/2020//.

Pfitzner, V.C. , Ulasan Atas 1 Korintus: Kesatuan dalam Kepelbagaian, Jakarta: BPK Gunung Mulia,2011.

Anderson, R. Dean., Surat 1 Korintus: Membereskan Jemaat Urban yang Muda, Surabaya: Momentum, 2018.

Fee, Gordon D., The International Commentary on the New Testament: The First Epistle to the Corinthians, GrandRapids, Michigan: William B. Eerdmans Publishing, 1988.

https://alkitab.sabda.org/commentary.php?book=46\&chapter=6\&verse=19//20/02/2 020//.

End, Th. van den, Tafsiran Alkitab: Surat Roma, Jakarta: BPK Gunung Mulia,2006. https://alkitab.sabda.org/commentary.php?book=rom\&chapter=12\&verse $=1 / 20$ /02/2020// Moo, Douglas, The International Commentary on the New Testament: The Epistle to the Romans, (GrandRapids, Michigan: William B. Eerdmans Publishing, 1996.

Houwelingen, P.H. R. van, Tafsiran Perjanjian Baru: Surat 1 Petrus, Surabaya: Momentum, 2018. h. van den End, Tafsiran Alkitab: Surat Roma, (Jakarta: BPK Gunung Mulia,2006), hlm. 653.

https://alkitab.sabda.org/commentary.php?book=rom\&chapter=12\&verse=1/20/02 /2020//.

Douglas Moo, The International Commentary on the New Testament: The Epistle to the Romans, (GrandRapids, Michigan: William B. Eerdmans Publishing, 1996), hlm. 754.

P.H. R. van Houwelingen, Tafsiran Perjanjian Baru: Surat 1 Petrus, (Surabaya: Momentum, 2018), hlm.100-101. 